\title{
HSTC Bulletin
}

Journal of the History of Canadian Science, Technology and Medecine

\section{Index, Volume VIII}

Volume 8, numéro 2 (27), décembre-december 1984

URI : https://id.erudit.org/iderudit/800201ar

DOI : https://doi.org/10.7202/800201ar

Aller au sommaire du numéro

Éditeur(s)

HSTC Publications

ISSN

0228-0086 (imprimé)

1918-7742 (numérique)

Découvrir la revue

Citer ce document

(1984). Index, Volume VIII. HSTC Bulletin, 8(2), 174-174.

https://doi.org/10.7202/800201ar

Tout droit réservé (c) Canadian Science and Technology Historical Association / Association pour l'histoire de la science et de la technologie au Canada, 1984
Ce document est protégé par la loi sur le droit d'auteur. L’utilisation des services d'Érudit (y compris la reproduction) est assujettie à sa politique d'utilisation que vous pouvez consulter en ligne.

https://apropos.erudit.org/fr/usagers/politique-dutilisation/ 


\section{ARTICLES :}

Baldwin, Douglas, 'Cobalt: Canada's Mining and Milling Laboratory, 1903-1918,' 95-111.

Beck, Boyde, 'Imperialism and Professionalization: Dominion Registration and Canadian Physicians during the Boer War,' 3-19.

De Vecchi, Vittorio, 'The Dawning of a National Scientific Community in Canada, 1878-1896,' 32-58.

De Vecchi, Vittorio, 'Science and scientists in Government, 1878-1896--part I,' 112-42.

Young, Gayle, 'Hugh Le Caine: Pioneer of Electronic Music in Canada,' 20-31.

RESEARCH NOTES :

Anderson, Frances, 'The Demise of the Fisheries Research Board of Canada: A Case Study of Canadian Research Policy,' 151-6.

Baker, Melvin, 'Henry Hunt Stabb and the Establishment of a Lunatic Asylum in St John's, Newfoundland, 1836-1855,' 59-67.

Hull, James, 'Early Membership of the Technical Section, Canadian Pulp and Paper Association,' 68-72.

Irwin, Ross, 'The Sylvester Auto-Thresher: A Canadian First in Grain Harvesting,' 143-50.

BOOK REVIEWS:

Cuming, Discovering Heritage Bridges on Ontario's Roads (Norman Ball), 73-4.

Howard, The Chief: Doctor William Osler (David Naylor), 157-8.

Inkster and Morrell, Metropolis and Province: Science in British Culture, 1780-1850 (Trevor Levere), 74-6.

Macdonald, Thorough. An Illustrated History of the College of Engineering, University of Saskatchewan, 1912-1982 (Norman Ball), 160-1.

Rasky, Industry in the wilderness: the People, the Buildings, the Machines--Heritage in Northwestern Ontario (Thomas Roach), 158-60.

St. Remy et al., A Catalogue of the Riche-Covington Collection (Richard Jarrel1), 161-2. 